\title{
The mammoth site of Niederweningen, Switzerland
}

\author{
Heinz Furrer ${ }^{\mathrm{a}, *}$, Hans Rudolf Graf ${ }^{\mathrm{b}}$, Andreas Mäder ${ }^{\mathrm{c}}$ \\ ${ }^{a}$ Paläontologisches Institut und Museum der Universität Zürich, Karl Schmid-Strasse 4, 8006 Zürich, Switzerland \\ ${ }^{\mathrm{b}}$ Matousek, Baumann \& Niggli AG, Mäderstrasse 8, 5400 Baden, Switzerland \\ ${ }^{\mathrm{c}}$ Kantonsarchäologie Zürich, Stettbachstrasse 7, 8600 Dübendorf, Switzerland
}

Available online 29 December 2006

\begin{abstract}
In 1890 more than 100 bones, molar teeth and tusks of at least seven different individuals of mammoths, including a very young calf, were found in a peat horizon at the base of a gravel pit at the village of Niederweningen, $20 \mathrm{~km}$ northwest of Zürich. Further fragmentary fossils have been identified as remains of woolly rhino, wild horse, bison, wolf, lemming, vole, frog and bird. In 2003 and 2004 new fossils and good sections of the peat horizon were studied in large construction pits located close to the old Niederweningen mammoth site. The highlight was a well-preserved articulated mammoth skeleton with an estimated height of about $3.50 \mathrm{~m}$. New ${ }^{14} \mathrm{C}$-AMS dating confirm that bones and teeth of mammoth, peat and wood found in association with mammoth, have an age of about $45 \mathrm{ka}$ BP. Luminescence dating of one section provides time control with ages of $70-80 \mathrm{ka}$ for the sediments below the peat and 40 ka above the peat. First studies on pollen, seeds, wood and beetle allow the reconstruction of environment and climate during this time interval in the middle part of the last glacial cycle (Middle Würmian).
\end{abstract}

(C) 2006 Elsevier Ltd and INQUA. All rights reserved.

\section{Introduction}

In July 2003, the discovery of a partly articulated mammoth skeleton in a construction pit at Niederweningen cast new light on the old 'Mammutloch' ('mammoth pit') excavated 1890 in the same village. Niederweningen is the most important mammoth site of Switzerland and is located about $20 \mathrm{~km}$ northwest of the city of Zürich (Fig. 1). However, the oldest documented finding of mammoth bones in Switzerland was in 1577 near the monastery of Reiden, north of Luzern. At the time, the bones were described by the physician Felix Platter from Basel as a giant of $6 \mathrm{~m}$ height, known later in the literature as the 'Giant of Reiden', 'Giant of Lucerne' or 'Swiss Giant'. Other historical mammoth fossils were found in sand and gravel pits of the Swiss midlands from Geneva to Lake Constance. For instance, more than 200 bones and teeth of the woolly mammoth are known since 1769 from the region of Basel (Engesser et al., 1996) and more than 60 from Kanton Zürich since 1821 (Hünermann, $1985,1987)$.

\footnotetext{
*Corresponding author. Tel.: +41446342323.

E-mail address: hfurrer@pim.unizh.ch (H. Furrer).
}

Similar bones and teeth, named 'Mammut' in Eastern Europe, were identified as elephant remains by the German naturalist Johann Friedrich Blumenbach in 1799 and described as Elephas primigenius. In 1806, a first skeleton of a mammoth was mounted at St. Petersburg, defrosted some years before as an almost complete carcass from the permafrost in Siberia. The impressive copperplate engraving by the naturalist W.G. Tilesius was adopted by nearly all textbooks of the 19th century. In 1821, the French anatomist Georges Cuvier interpreted the mammoth as an extinct elephant, well adapted to a cold climate due to its thick hairs. Today scientists call the woolly mammoth, restricted to the Late Pleistocene, Mammuthus primigenius (Blumenbach, 1799).

The woolly mammoth arose in Northeastern Siberia probably around $800,000 \mathrm{yr}$ ago but appeared in Europe only about $200,000 \mathrm{yr}$ ago (Lister and Sher, 2001). Near the Pleistocene/Holocene boundary the last mammoths disappeared from Europe and the mainlands of Asia and North America (MacPhee et al., 2002). Only isolated populations of mammoths survived in Alaska, with bones dated at 7000 cal. yr BP found on St. Paul Island (Guthrie, 2004) and on Wrangel Island in northern Siberia, where youngest fossils of dwarfed mammoths were dated at 3700 ${ }^{14} \mathrm{C}$ yr BP (Vartanyan et al., 1993; Kuzmin et al., 2003). 


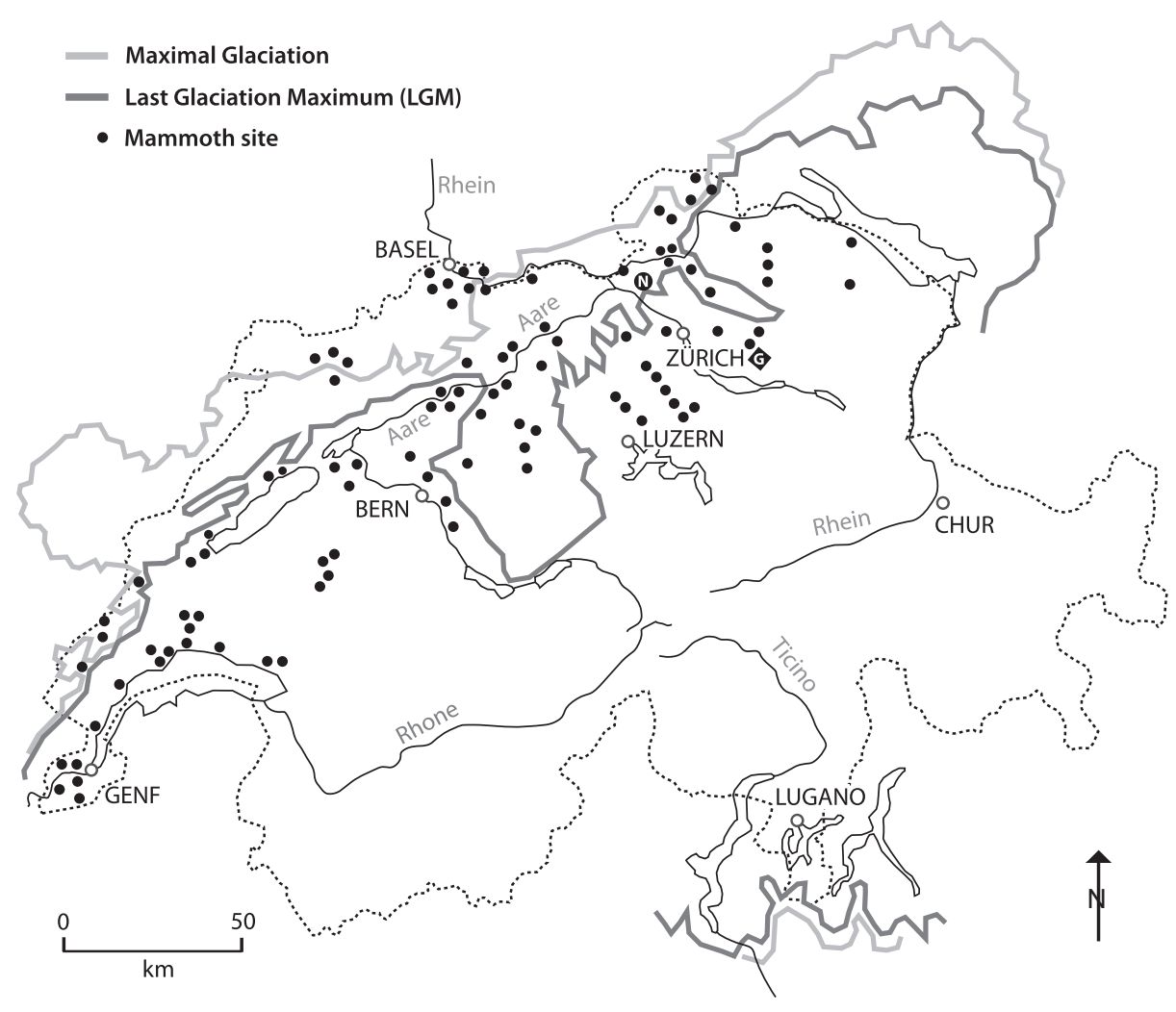

Fig. 1. Overview on the mammoth sites in Switzerland, spread on the whole Swiss midland and Jura mountain. The Niederweningen mammoth site is marked by 'N'. No vertebrate fossils have been found at the Gossau interstadial site 'G'. The outer line follows the maximal extent of Alpine glaciers; the inner line the Last Glacial Maximum (LGM).

Radiocarbon ages of bones found in Switzerland indicate that mammoths were present in this area until the Late Glacial. The most complete skeleton from Praz Rodet (Weidmann, 1970) is known from the literature to have an uncalibrated age of 12,270 yr BP (Engesser et al., 1996), but recent dating indicates an older age of $13,705 \pm 55{ }^{14} \mathrm{C}$ yr BP or 16,300 cal. yr BP (R. Marchant, pers. comm.). The youngest mammoth bone from northern Switzerland was found in Late Glacial gravels at Uster and was dated in 1988 to an age of $13,350 \pm 260{ }^{14} \mathrm{C}$ yr BP. Several bones and teeth from gravel pits in the area of Rafz, Hüntwangen, Wil and Weiach (Rhine valley) have uncalibrated ages between 18,000 and $22,000{ }^{14} \mathrm{C}$ yr BP. Other mammoth sites in Switzerland yield fossils that are older, but still in the range of the ${ }^{14} \mathrm{C}$ dating method. The tusk found at Sylleux Ajoie, Swiss Jura, was dated to $31,595 \pm 1335$ cal. yr BP (Aubry et al., 2005). An interesting find at Obfelden (Reuss valley) was dated between 37,000 and $43,000{ }^{14} \mathrm{C}$ yr BP (Hünermann, 1985). The oldest mammoth finds in Switzerland, from the area of Gondiswil, have been dated only by pollen analysis of the enclosing peat (lignite) to an age of $48,000-55,000 \mathrm{yr}$ (Wegmüller, 1992). An outstanding mammoth site is Siegsdorf in south-eastern Germany, where almost complete skeletons of a huge male mammoth and a cave lion were excavated in 1985 from silty clay (Ziegler, 1994). The AMS date of the cave lion is $47,180+1190 /-1040{ }^{14} \mathrm{C}$ yr
BP (Burger et al., 2004), the age of the mammoth itself is $45,180 \pm 1130{ }^{14} \mathrm{C}$ yr BP (R. Dagra, pers. comm.).

\section{The 'mammoth pit' of Niederweningen $1890 / 91$}

In 1890, spectacular fossils were discovered at Niederweningen, when a thin bed of gravel was exploited for the construction of the new railway embankment ('mammoth pit' in Fig. 2). During the excavation led by the zoologist Arnold Lang from Zürich University in 1890 and the summer of 1891, more than 100 bones, molar teeth and tusks of at least seven different mammoth individuals, including a very young calf, were found in a peat horizon and in the overlying silt at the base of the 3-4 m thick gravel bed (Lang, 1892). Other fragmentary fossils were identified as remains of woolly rhino, wild horse, bison, wolf, vole, frog and bird, together with insect and plant remains. In a revision of the fauna, Hünermann (1987) listed Mammuthus primigenius, Coelodonta antiquitatis, Equus przewalskii, Bison priscus, Canis lupus, Arvicola terrestris, Lemmus lemmus, and Rana temporaria, later followed by a description of vole (arvicolid rodents) (Hünermann, 1989). Already in 1892, A. Lang mounted an impressive reconstruction at Zürich, being aware that the original skeletal elements came from five different individuals (Fig. 3). Since 1914 the Niederweningen mammoth was one of the highlights of the Zoological 


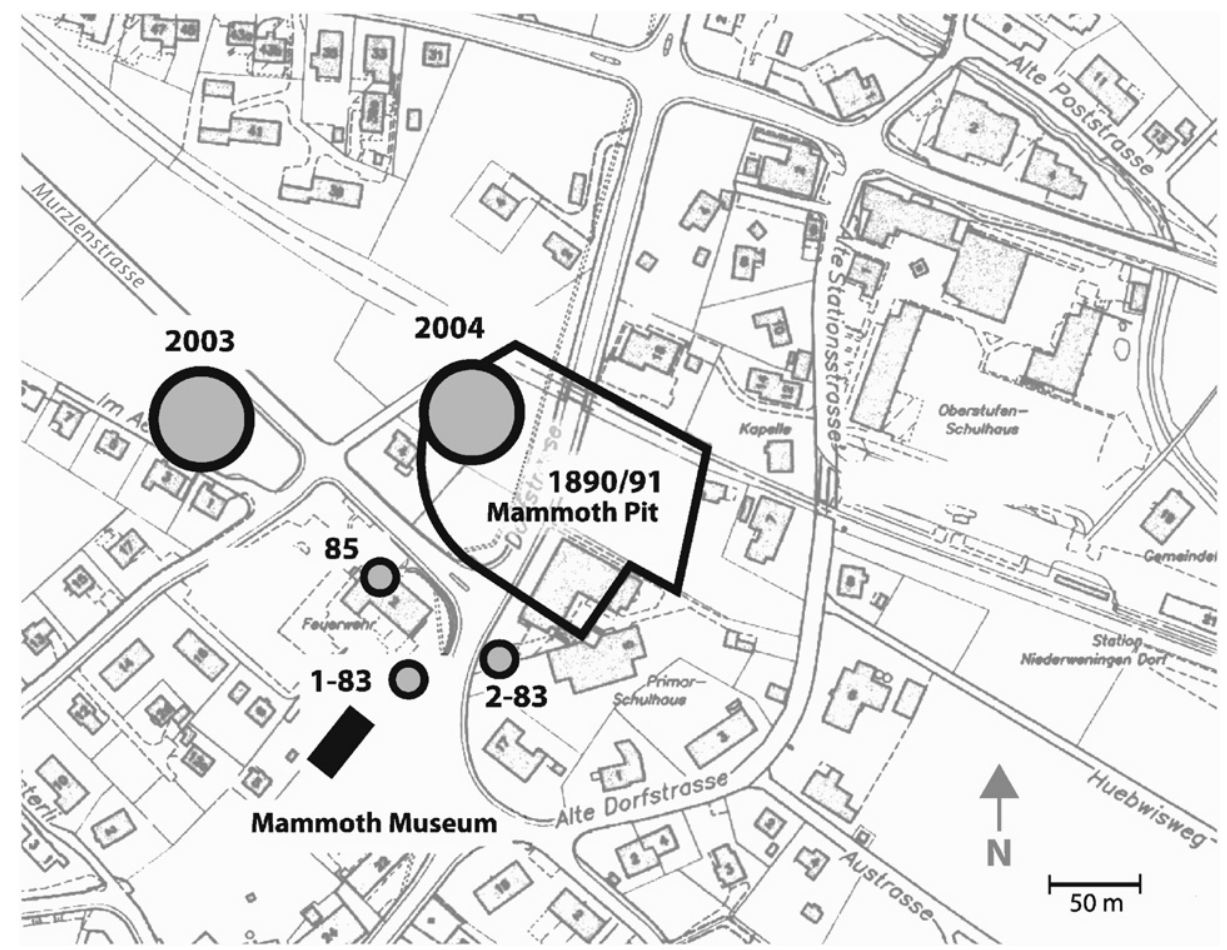

Fig. 2. Map of Niederweningen with the position of the Mammoth Museum near the sites 1890/91 'mammoth pit'; 1-83, 2-83, 85 core holes 1983 and 1985; 2003 construction pit Murzlenstrasse and 2004 construction pit Mammutweg.

Museum in the new building of the university. Years later, however, when more and better-preserved carcasses of mammoth were found in the permafrost of Siberia, it was obvious that the tusks had been placed the wrong way round. An anatomically correct reconstruction of an adult mammoth skeleton, with original bones from Niederweningen has been on exhibit since 1991 in the Zoological Museum of Zürich University.

\section{Sections in construction pits and bore holes until 1990}

The scientific importance and the age of the mammoth peat has been controversial. Heim (1919) wrote in his famous textbook about the geology of Switzerland of a 'postglacial peat at Niederweningen' because he noticed that glacial deposits do not cover the locality. Pollen analysis of two cores taken in 1983 near the mammoth pit $(1-83,2-83)$ indicate that a peat found $7-9 \mathrm{~m}$ below the surface was deposited during the Last Interglacial (Eemian) and at the beginning of the last glaciation (Würmian) (Welten, 1988). Another core drilled in 1985 on the site of a planned building south of the mammoth pit provided evidence for two different peat horizons: an upper peat from 3.0 to $4.5 \mathrm{~m}$, overlaying $6 \mathrm{~m}$ silty sands, and a thicker lower peat from 10.0 to $12.6 \mathrm{~m}$ (Schlüchter, 1988). These two peat horizons were not studied by palynologists but a lithostratigraphic correlation suggests that the lower peat corresponds to the interglacial peat of core 2-83 studied by Welten (1988) and the upper peat to the mammoth peat of Lang (1892).
During the excavation of the construction pit in 1987, the upper peat was unearthed extensively, displaying remarkable diapir-like features and shear zones (Schlüchter, 1988, 1994). Similar deformation results today from cryoturbation in swampy areas of the tundra in Siberia, Northern Scandinavia and Northern Canada (Strunk, 1983). In this peat, sometimes rich in moss, twigs of Betula, beetles, and a small bone fragment were found. In 1990, another construction pit in the eastern part of the mammoth pit (school building 'Mammutwies') unearthed only thin but strongly deformed lenses of peat. Bones from 1890 to 1987 were dated in the late 1980 s at $33,300+420$ and $34,600 \pm 480{ }^{14} \mathrm{C}$ yr BP. The dating of plant material from the upper part of the peat 1987 was controversial $\left(33,100 \pm 340\right.$ and $42,330 \pm 1590{ }^{14} \mathrm{C}$ yr BP) (Schlüchter, 1994). Radiocarbon ages of bones from the mammoth pit 1890/91 and the upper peat 1987 are thus much younger than the deep buried peat in core 2-83, dated by Welten (1988) as Eemian and Earliest Würmian.

The earlier Quaternary history at Niederweningen itself is not well known. A precursor of the Wehntal valley already existed during deposition of the 'Tiefere Deckenschotter' (Lower Cover Gravels) in the Early Pleistocene. The widening of the valley to its actual size and the strong erosion deep below its actual level into the Molasse bedrock was forced by Middle Pleistocene glaciers. The exact time of formation of this glacial basin is not known. A hydrogeological coring near Schleinikon/Oberweningen ( $2 \mathrm{~km}$ east of Niederweningen) in 1994 stopped at a depth of $127 \mathrm{~m}$, without reaching the bedrock (Graf and Müller, 


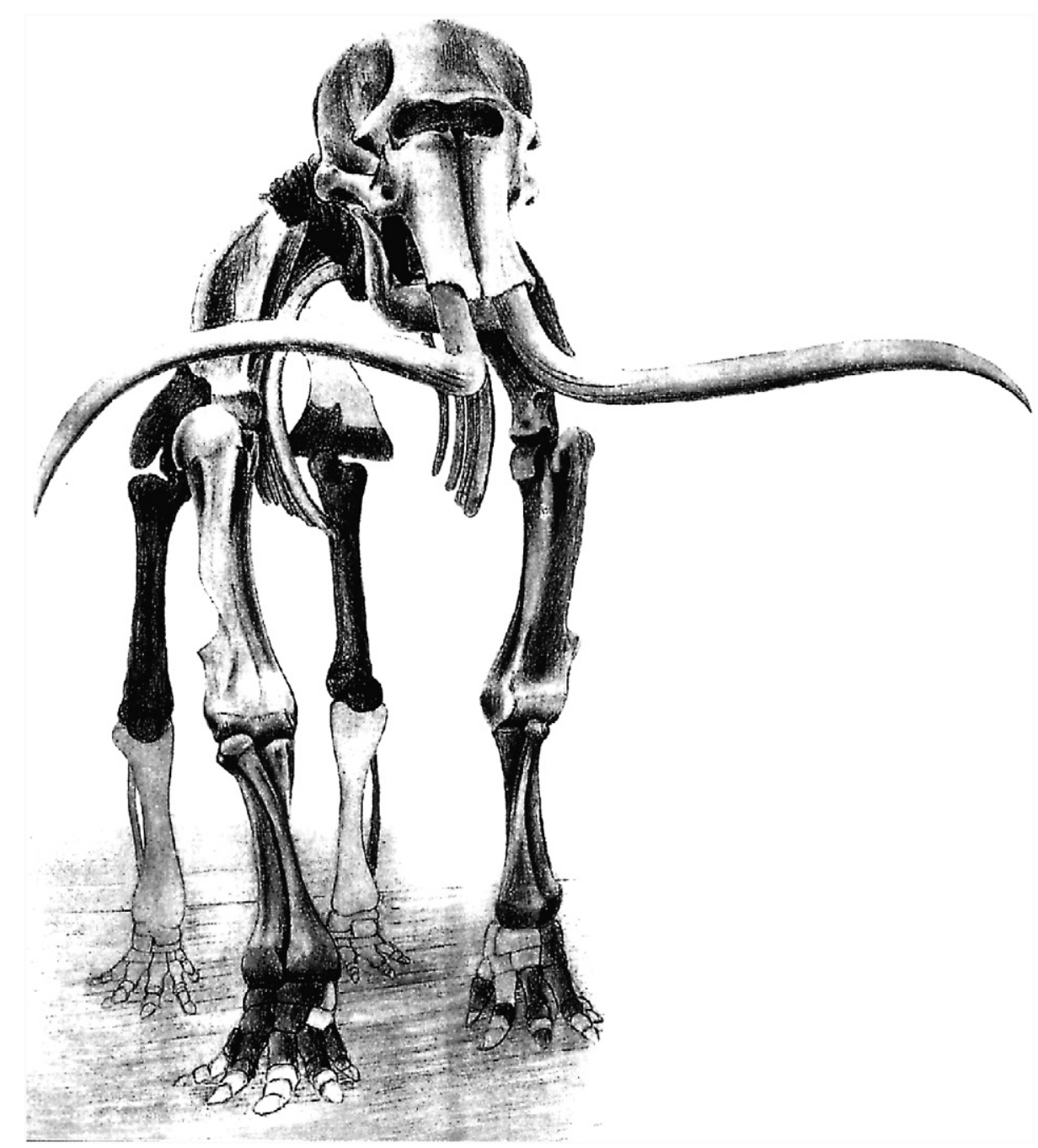

Fig. 3. The old composite reconstruction of the Niederweningen mammoth in the Zoological Museum of Zurich University (Lang, 1892).

1999). In that drilling, the uppermost gravel unit is interpreted as deposits of the youngest advance of Linth glacier into the Glatt Valley. The accompanying terminal moraine ( $\mathrm{LGM}=$ Last Glacial Maximum) is well exposed between Schöfflisdorf and Steinmaur, $4 \mathrm{~km}$ east of Niederweningen. Below the gravel and coarse grained sediments deposited by a local creek, a sequence of peat with an age of about $40,000 \mathrm{yr}\left(39,510 \pm 730\right.$ and $39,820 \pm 750{ }^{14} \mathrm{C} \mathrm{yr}$ BP) marks at a depth of $17 \mathrm{~m}(447 \mathrm{~m}$ a.s.1.) the top of a shallowing upward sequence from lake to swamp deposits, rather similar to the sequence at Niederweningen. Below a depth of $18 \mathrm{~m}$, the core section displays mainly fine-grained lacustrine sediments attributed to cold environmental conditions. The core sediments point to at least two glacial events before the last glacial cycle (Würmian). It is not yet known whether these deposits document a two-phase penultimate glaciation or if the deeper sequence is even older. In his pollen analysis of core 2-83, Welten (1988) described a $2 \mathrm{~m}$ thick palaeosol below the Eemian, probably from the penultimate glacial cycle. In the lowermost part of the core, he found pollen from the latest phase of a previous interglacial.
A schematic section of the Late Pleistocene and Holocene deposits at Niederweningen, based on core descriptions by Schlüchter $(1988,1994)$ and Welten (1988) and new data collected during the studies in the construction pits 2003 and 2004 (see below) displays the present stratigraphic interpretation (Fig. 4).

\section{New mammoth findings at Niederweningen in $\mathbf{2 0 0 3}$}

In July 2003, the lower jaw of a mammoth was discovered in a construction pit only $100 \mathrm{~m}$ west of original mammoth 1890/91 pit (Fig. 5). In an emergency 3-week excavation, the Palaeontological Institute and Museum of the University of Zürich and the Archaeological Survey of Kanton Zürich recovered teeth and bones of a partially articulated mammoth skeleton. The site was documented carefully with maps, geologic sections and sampling for pollen analyses and other palaeobotanical studies. The unique situation of a mammoth skeleton found in a peat level attracted the interest of the media and the public. The good preservation of plant material as seeds, leaves, spruce cones and wood, together with the amount of insects 


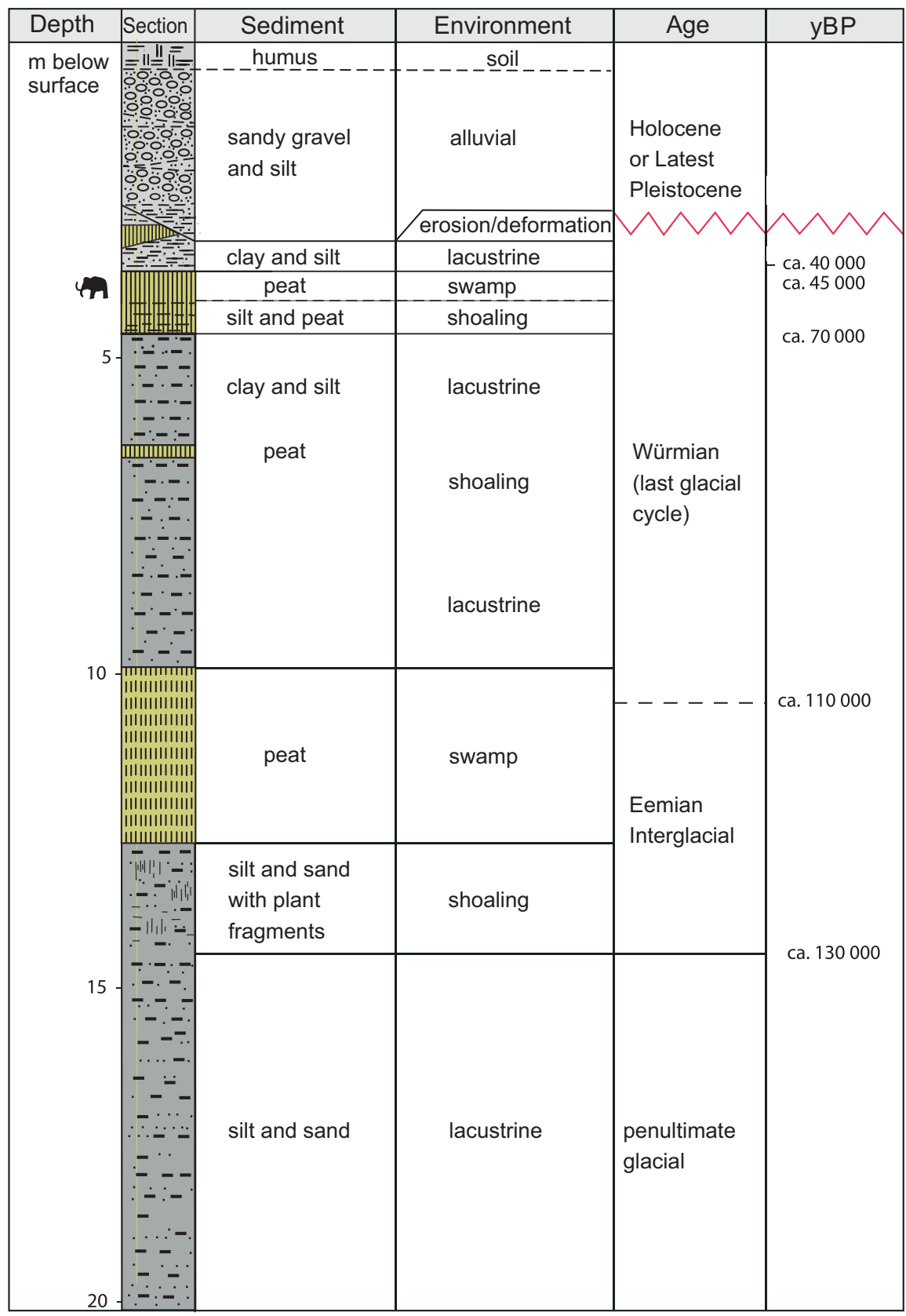

Fig. 4. Schematic stratigraphic section of the mammoth site Niederweningen (modified after Schlüchter 1988; Welten 1988).

offered a unique opportunity in an interdisciplinary project by specialists in palaeozoology, palaeobotany, palynology, geology, geochronology, geochemistry and archaeology (Furrer, 2005).

About $50 \%$ of a large mammoth skeleton (Mammuthus primigenius) were embedded in the peat (Fig. 6): a wellpreserved lower jaw with two molars (m3 sin. et dext.); crushed fragments of a skull with four isolated molars (M3 sin. et dext. and nearly completely worn M2 sin. et dext.); crushed proximal parts of both tusks; all neck vertebrae with underlying hyoid bones in place, but only few fragments of dorsal vertebrae and four ribs; the complete left fore and hind limbs with strongly broken femur; and a fragmentary pelvis covering three bones of the right foot. Most of the bones from the vertebral column, the tail, the hip and shoulder girdle, but also the right fore and hind limbs were missing. The dimensions of the limb bones and the tusks suggest a woolly mammoth with an estimated shoulder height of about $3.50 \mathrm{~m}$. The slight wear of the wellpreserved last molars indicates that the mammoth died at an age of about 40 years. No other vertebrate fossils have been found at this place but insects were quite common (Coope, 2007). 
The mammoth was discovered at the eastern end of the construction pit and was embedded in the upper $30 \mathrm{~cm}$ of the $80-100 \mathrm{~cm}$ thick main peat. A NE-SW directed section was drawn at the eastern wall of the pit, completed later by the section in a trench cut out just after the recovery of the bones (Fig. 7). The mammoth peat was overlain by grey

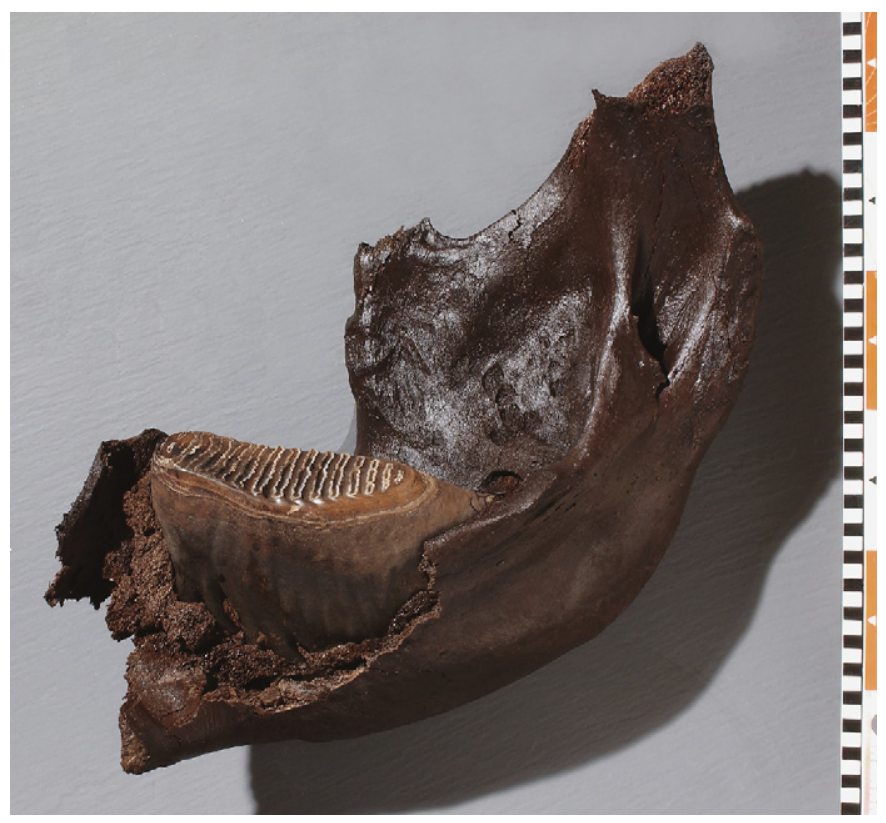

Fig. 5. One of the fragments of the mammoth jaw, cut by the excavator in the construction pit 2003 at Niederweningen (photo H. Lanz, Paläontologisches Museum Universität Zürich). (greenish-bluish) clay and silt and lenses of an upper peat, locally rich in wood pieces. This thin upper peat was locally cut and covered by brown silt and sandy gravel, interpreted as alluvial deposits (from a creek). Just north of the skeleton, the peat dipped downwards along a series of listric faults, cutting also through the proximal part of both tusks. North of the faults towards the valley axe, the mammoth peat was thinned out to $20-30 \mathrm{~cm}$ and covered by clay and silt with lenses of peat and pebbles. In the trench, cut after the recovery of the bones into the base of the construction pit, another peat horizon was evident $1 \mathrm{~m}$ below the mammoth peat. The thin lens-like peat had been folded together with the grey clay and silt including lenslike intercalations of pebbles and sand.

\section{The latest construction pit at Niederweningen 2004}

In March and April 2004 another construction pit, called 'Mammutweg', was opened at Niederweningen just at the western end of the 1890/91 mammoth pit (Fig. 8). In the southwest edge of the deepest pit, a $1.1 \mathrm{~m}$ thick peat horizon was exposed, just outside of the old mammoth pit. The section started at the bottom with 2-3 $\mathrm{m}$ of grey clay, silt and sand, followed by dark silt layers rich in organic material. The middle part was characterised by organic silt with wood fragments and clasts of dark peat. The uppermost $20 \mathrm{~cm}$ of mossy peat are overlain by a thin bed of grey clay and silt. This peat and clay sequence was covered by $3-4 \mathrm{~m}$ of brown gravel exploited in 1890 for the railway embankment. The new exposure showed that the

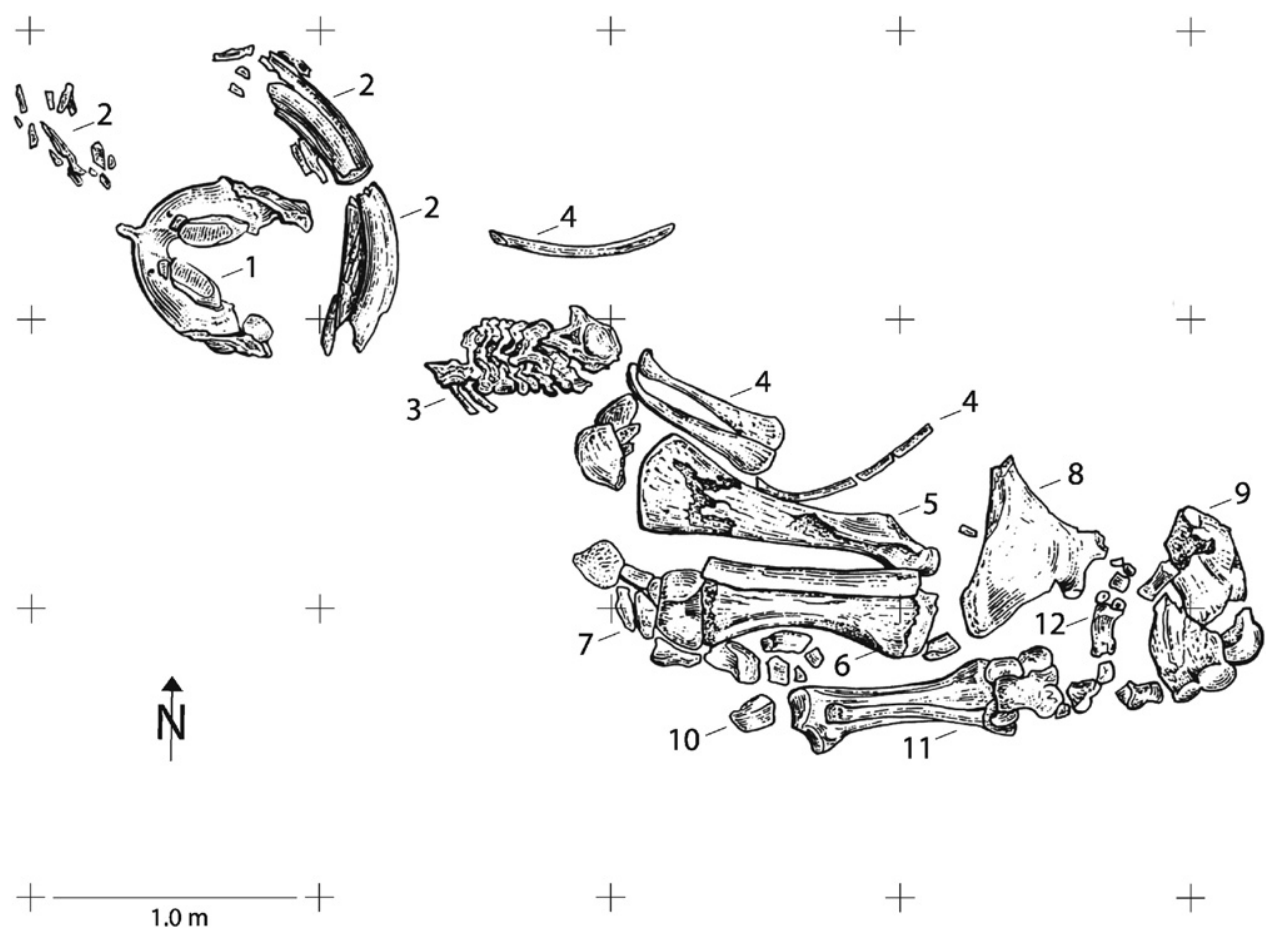

Fig. 6. Plan of the articulated mammoth skeleton, preserved in the construction pit 2003 at Niederweningen. 1: lower jaw, 2: fragments of tusks, 3: neck vertebrae and hyoid bones, 4: ribs, 5: humerus sin., 6: ulna and radius sin., 7: bones of left forefoot, 8: pelvis fragment, 9: fragmentary femur sin., 10: patella sin., 11: tibia and fibula sin.,12: bones of left hind foot (drawing B. Scheffold, after documents of the Kantonsarchäologie Zürich). 


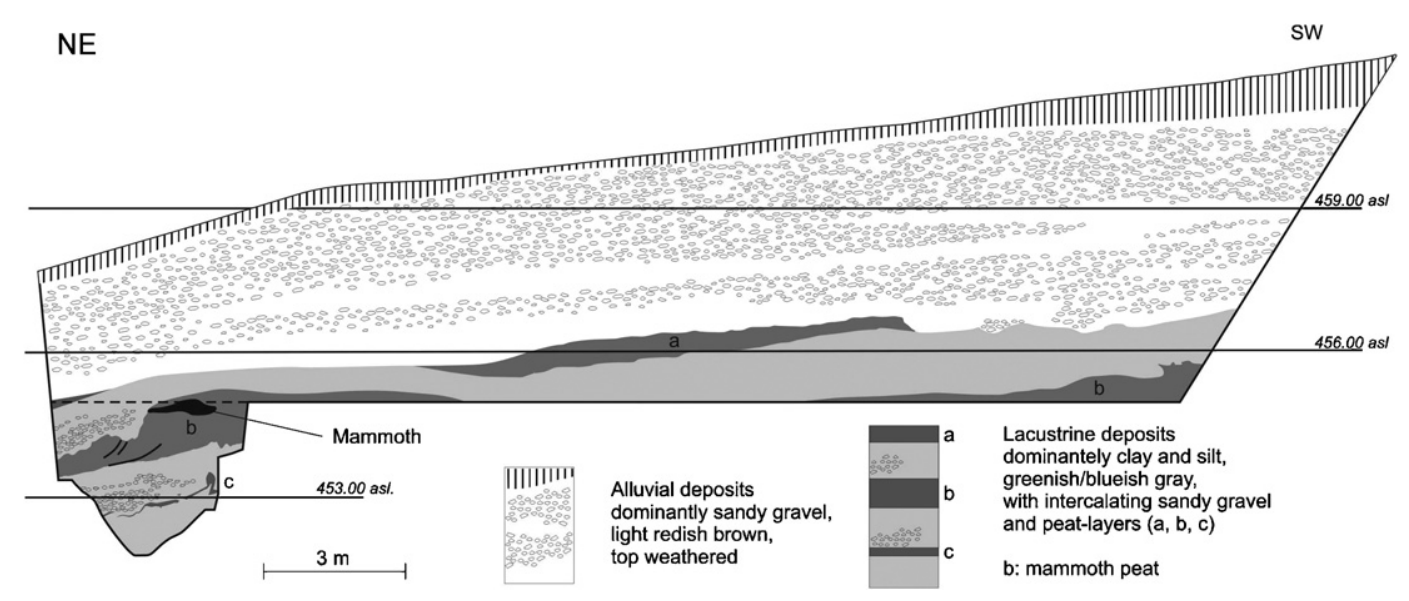

Fig. 7. Geological section at the eastern wall of the construction pit 2003 at Niederweningen, completed by the section in a trench below the mammoth site (drawing H.R. Graf).

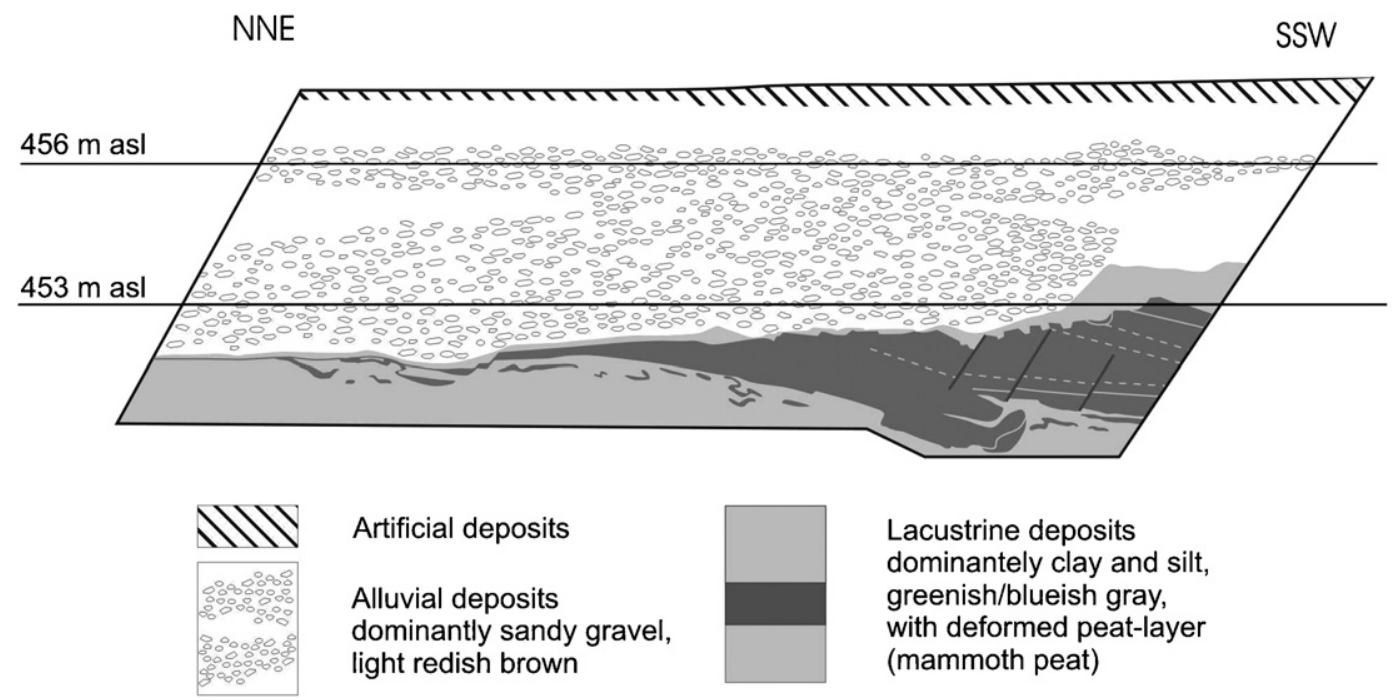

Fig. 8. Geological section at the western wall of the construction pit 2004 at Niederweningen. The $1.1 \mathrm{~m}$ thick peat horizon (mammoth peat) is thinned out north wards by diapir-like updoming, faulting and erosion (drawing H. Furrer/H.R. Graf).

sequence of the mammoth peat and the embedding lake sediments were strongly deformed by diapir-like structures, faults and reworking. The western wall of the largest pit displayed an important thinning of the peat, due to listric faults and updoming. The section corresponds quite well to the sequence at the mammoth site 2003 , but no vertebrate fossils have been found here. Large peat samples for future palaeobotanic studies have been recovered. Luminescence dating was done on samples from this section (Preusser and Degering, 2007).

In the central part of the new construction pit only strongly deformed and re-sedimented peat lenses have been excavated. At last, when an additional trench was cut into the base of the construction pit, bones were found in a $1-2 \mathrm{~m}$ thick lens of silt rich in brown organic matter. Most of the bones were found as broken but not worn fragments in the silt together with clasts of typical peat and limestone pebbles. Several fragments of ribs, vertebrae, limb bones but also scattered fragments of a lower jaw with a strongly worn molar and even a complete tusk $2.5 \mathrm{~m}$ in length, all found on a surface of about $45 \mathrm{~m}^{2}$, may originate from an old male mammoth. One isolated carnivore tooth is from hyena Crocuta crocuta spelaea (W. Brinkmann, pers. comm.). Two finds of fragmentary bones of birds and many skeletal remains of a frog (Rana temporaria) document additional faunal elements. Meantime, about 30 isolated teeth and few lower and upper jaw fragments of Arvicola terrestris and other voles and shrews have been collected by washing and sieving about $300 \mathrm{~kg}$ of this material. A study on these micromammals is in progress. 
It is remarkable that two metapodials and a fragmentary tusk of mammoth were discovered in May 2004 also in the grey silt just above a peat lens in the southern wall of the construction pit. A mammoth tusk and bison bones had been found already 1890 in a similar position above the peat (Lang, 1892). It is possible that these bones and tusks had been washed out after deposition of the peat and embedded later in a secondary position in the overlying sediments.

\section{Stratigraphy and chronology}

The stratigraphic position and age of the mammoth peat at Niederweningen is controversial (Schlüchter, 1994). The new fossils and outcrops in both construction pits 2003 and 2004 solved some problems and provided a schematic stratigraphic section of the Late Pleistocene deposits at Niederweningen (Fig. 4) based on the most complete core (core 85, Schlüchter, 1988). As Welten (1988) showed, a thick peat found $7-9 \mathrm{~m}$ below the surface in the core 2-83 was deposited during the Last Interglacial (Eemian) and at the beginning of the last glacial cycle (Earliest Würmian). We presume that the $5 \mathrm{~m}$ thick lower peat in a depth of more than $10 \mathrm{~m}$ in core 85 (and in the schematic section) can be correlated with this time interval (Fig. 10).

The $1 \mathrm{~m}$ thick mammoth peat displays different pollen associations partly dominated by Picea (Drescher-Schneider et al., 2007). Since the available radiocarbon dating (AMS) results of bone and plant material from 1890 and 1987 varied between 33,000 and $42,000{ }^{14} \mathrm{C}$ yr BP (see above, Schlüchter, 1994), a new effort was made. New measurements on bone, teeth and plant material from the mammoth site 2003 by Hajdas et al. (2007) revealed an age of about $45,000{ }^{14} \mathrm{C}$ yr BP for the upper part of the peat with the mammoth skeleton. Luminescence dating of the most complete section in the construction pit 2004 provided time control with an age of $80,000-70,000 \mathrm{yr}$ for the sediments below the peat and of about $40,000 \mathrm{yr}$ above the peat, thus in good agreement with the radiocarbon chronology (Preusser and Degering, 2007).

The lower and middle parts of the mammoth peat in the 2004 construction pit were rich in silt and intercalated grey silt layers. Pieces of wood and even reworked clasts of peat indicate a resedimentation by currents in a shoaling lake, probably influenced by an incoming local creek from the Lägern Hill. The upper part is a very compressed peat with moss, seeds and fragments of twigs and wood up to $20 \mathrm{~cm}$ in length. The absence of vertical root structures suggests a deposition in a swamp or marsh with very high water level.

The mammoth peat is always overlain by $30-80 \mathrm{~cm}$ of grey laminated silt. Locally large depressions seem to be cut in the uppermost part of the peat (interpreted formerly by Lang, 1892 as mammoth trampling). Some of the depressions are filled by grey silt with lenses of re-deposited peat. Larger scale winnowing and reworking of peat material including skeletal material of vertebrates is proved by the above-described situation in the 2004 construction pit. Lenses or local intercalations of pebbles near the base of the silt have been found only in areas with reduced thickness of the peat. Sedimentary deformation such as diapir-like up-doming of peat and listric faults, cutting through and thinning the peat horizon, are quite common and affected also the overlaying grey silt. These processes of sedimentary gliding and mobilisation took place during or after deposition of the grey silt, hence, during or after flooding of the swamp plain that stopped the growth of vegetation.

Only in core 85, the construction pits 1987 and 2003, situated near the flank of the valley, a thin upper peat horizon was found about $1 \mathrm{~m}$ above the mammoth peat. The $10-50 \mathrm{~cm}$ thick peat was locally rich in wood fragments, mainly broken pieces of large stems of spruce trees (Picea sp.), sometimes associated with complete Picea cones and even some fragmentary bones. The ages of a Picea cone $\left(44,520 \pm 1080{ }^{14} \mathrm{C}\right.$ yr BP) and a wood piece $\left(42,620 \pm 780{ }^{14} \mathrm{C}\right.$ yr BP) (Hajdas et al., 2007) from this upper peat are similar to the age of the upper part of the mammoth peat. It is possible that this upper peat documents a short and slightly younger peat growth. Another explanation could be reworking of older plant material, transported by a flooding event from the slope of the valley.

The contact with the overlying sand and gravel is very sharp and must be interpreted as a major unconformity. It is usually rather flat with minor depressions interpreted as flute and load structures during rapid deposition phases. These sediments of restricted spatial extent are interpreted as fan like alluvial deposits of a local creek coming from the northern slope of Lägern Hill, redepositing older glacial material and weathered mesozoic limestone. The age of these deposits is unknown; it could be Late Pleistocene or Early Holocene.

\section{Habitats and palaeoclimate}

The study of pollen, wood and other plant material from the $80-100 \mathrm{~cm}$ thick peat horizon at the 2003 mammoth site suggests a long shoaling phase of a former Wehntal lake, building swamps and marshes. In the lower part of the peat the amount of tree pollen is very low, interpreted to indicate unfavourable conditions for tree growth on the surrounding slopes (Drescher-Schneider et al., 2007). During the following period climate improved and the valley was partly covered by open mixed forest of Picea, Betula and Larix characterised as forested tundra (Fig. 9) Vegetation of the middle part of the peat reflects growth in marshes and wet meadows in a frequently flooded valley plain. Carex sp. is common but reed has not been found. Shrub and tall herb species grew probably at the border of the swamp or along natural dams of local creeks. A rich flora of subalpine meadows and stony habitats was typical for the upper slope, especially above the timber-line on the northern part of Lägern Hill. 


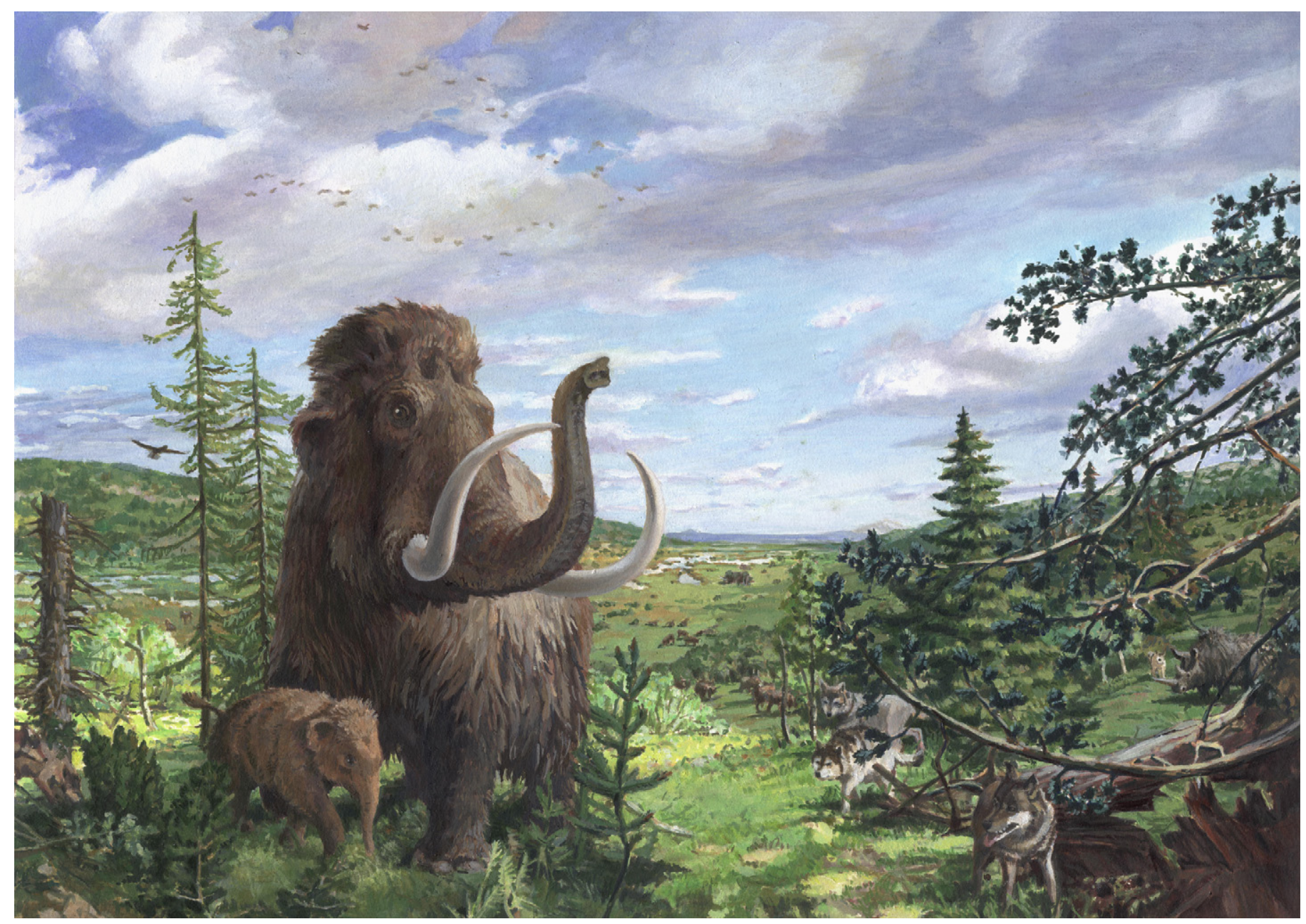

Fig. 9. Reconstruction of the fauna and flora in the landscape at Niederweningen $45000 \mathrm{yr}$ BP. On a warm summer day, a female mammoth with its young calf is aware of a group of wolves. In the open mixed woodland a woolly rhino hides behind with Picea and Larix (right). Wild horses, bison and other mammoths feed in the wet meadows and Carex marshes of the valley with patch-like ponds, swamps and peat bogs (painting Atelier Bunter Hund, Zürich).

The upper part with the embedded mammoth skeleton is an almost pure moss-peat but Sphagnum or other typical plants from peat bogs are rare. The climate corresponds to the situation near the tree line in the Alps and Jura mountains of today, with warm summer and cold winter with heavy snowfall (Drescher-Schneider et al., 2007).

In the uppermost part of the mammoth peat, the pollen spectrum reflects the end of favourable climatic conditions. Tree pollen decrease and the diverse herb vegetation implies a more open type of vegetation. At the 2003 site plant fossils from aquatic habitats are only documented in the uppermost part. On the other hand, the peat in the 2004 construction pit was rich in seeds of aquatic plants as Menyanthes, Potomageton, Ranunculus and oogonians of the characean algae Chara. At this site near the valley axe, ponds or other aquatic habitats are also indicated by fish teeth and many bones of the frog Rana temporaria.

The different vegetation types are confirmed and complemental by the study of insects, mainly beetles (Coleoptera), by Coope (2007) carried out on the same peat section at the 2003 mammoth site. Species from aquatic habitats and other species from reed swamps and marshes are quite common. Some are typically found in Sphagnum bogs. A large number of the Carabidae today live in habitats shaded by tall herbs. Some phytophage beetles feeding on Salix, Betula or conifers confirm mixed woodland and many of the scavenging beetles today prefer alpine and subalpine habitats. Some of the beetles do not live in Middle Europe anymore but are found in northern Scotland, Fennoscandia, Siberia, northern Canada and Alaska.

Coope (2007) also estimated palaeotemperatures from Coleoptera assemblages within the lower part of the mammoth peat ( $T_{\max }$, between 8 and $11^{\circ} \mathrm{C} ; T_{\min }$, between -20 and $-9{ }^{\circ} \mathrm{C}$ ), and the upper part of the mammoth peat ( $T_{\max }$, between 12 and $13^{\circ} \mathrm{C} ; T_{\min }$, between -12 and $\left.-5^{\circ} \mathrm{C}\right) . T_{\max }$ is the mean temperature of the warmest month (July) and $T_{\min }$ is the mean temperature of the coldest months (January and February). For comparison, the present-day air temperatures at Zürich Airport are $18^{\circ} \mathrm{C}\left(T_{\max }\right)$ and $-1{ }^{\circ} \mathrm{C}\left(T_{\min }\right)$. Similar climatic conditions are presently found near to the northern limit of boreal 
forest (Taiga) in Siberia. Corresponding values are calculated by Tütken et al. (2007) on the base of oxygen isotope composition of tooth enamel from the 2003 mammoth skeleton and fossils from other vertebrates found in 1890/91. By this method, the annual temperature was estimated to be $3-9^{\circ} \mathrm{C}$ cooler than today with $8.5^{\circ} \mathrm{C}$ at Zürich Airport.

\section{Palaeoecology and taphonomy of the mammoth bed}

The mammoth skeleton 2003 was found embedded in the upper $30 \mathrm{~cm}$ of the $80-100 \mathrm{~cm}$ thick main peat. The matrix is a highly compressed Cyperaceae- and moss-peat, representing typical mire vegetation (Drescher-Schneider et al., 2007). Root structures have not observed. Pieces of wood (mainly Picea sp., but also Betula sp., Lonicera sp. and Salix sp.) and Picea-cones must have transported in by storms and floods, suggesting single trees or small groups of trees on surrounding higher areas. The palaeobotanical investigations by Drescher-Schneider et al. (2007) reveal open woodland as found today at the transition from boreal forests to tundra in northern Europe or Siberia. The palaeoclimate corresponds to the situation near the tree line in the Alps and Jura mountains of today, with warm summer and cold winter with heavy snowfall (DrescherSchneider et al., 2007).

The fossil fauna recovered since 1890 from Niederweningen is dominated by herbivores, mainly mammoth but also woolly rhino, horse, bison, vole and lemming. Voles probably lived there the whole year, but the other mammals could have wandered through the valley due to seasonal migration. Mammoths were capable to digest $150-300 \mathrm{~kg} /$ day of nutrient-poor plants with high fiber contents (Guthrie, 1982). They fed mainly on grasses and sedges in the "mammoth steppe" although bark and twigs of trees and bushes like Larix, Salix, Alnus and Betula constituted a small part of their winter diet, noticed in mammoth stomach contents from frozen carcasses (Olivier, 1982; Vereshchagin and Baryshnikov, 1982; Bocherens, 2003) as well as dung boluses (Mead et al., 1986). The carbon isotope composition of teeth and bones from the 2003 Niederweningen mammoth skeleton but also from mammoth, woolly rhino, horse and bison found in 1890/91 indicate a pure C3-plant diet (temperate/arctic graminoids, shrubs and trees; Tütken et al., 2007). The low variability of enamel $\delta^{13} \mathrm{C}$ values of several mammoth teeth suggests a relative uniform and possibly restrained diet. The $\delta^{18} \mathrm{O}$ values reflect the mean oxygen isotopic composition of the palaeo-precipitation as they are similar to directly measured for Late Pleistocene groundwater from aquifers in northern Switzerland and southern Germany (Tütken et al., 2007). So the expected seasonal migration must be restricted to this area.

The arrangement of the articulated bones from the left fore and hind limbs of the mammoth skeleton 2003 suggests that the animal sunk into the mire and could not escape. We do not know why and in what season this tragedy happened. The peculiarity that the femur of the left hind limb was broken into several pieces and dislocated from the lower leg bones is not convincing for a severe injury in lifetime. Before discovery of the partial skeleton, a $20 \mathrm{t}$ machine excavated the construction pit and uncovered the uppermost part of the peat, possibly crushing and destroying the upper part of the fossil skeleton. As all bones were totally embedded in the uppermost $30 \mathrm{~cm}$ of the peat, the animal must had come in after deposition of most of the organic matter in the swamp but before deposition of the overlying grey clay and silt. The curious rarity of beetles associated with dung or carcasses in the Niederweningen mammoth peat suggest that there was no dung immediately available in the neighbourhood and that there were no carcasses during peat growth (Coope, 2007). It is likely that the mammoth became mired in a cooling phase just at the end of peat growth, when the surface of the swamp was frozen during much of the year but become a dangerous quagmire as it thawed during the brief summer months.

Another open question remains, why only the head and the left extremities of the animal have been found in the peat. The shoulder girdle and most of the backbones, the hip and tail but also the right fore and hind limbs were missing. Scavenging by predators is unlikely because no bite marks have been observed on the bones. Human presence is also not recorded from north-eastern Switzerland for Middle Würmian times (Late Mousterian, Late Palaeolithic). An isolated tooth from St. Brais and a fragmentary upper jaw of Homo neanderthalensis from Cotencher are the only documents of humans in Switzerland at this time (Le Tensorer and Niffeler, 1993). Although the climate and environment was quite favourable during this time, no fossils or artefacts were recovered at the Niederweningen sites. Recent archaeological studies on the 2003 mammoth skeleton revealed no marks or striations on the fossil bones as would be expected if humans fleshed out animals using stone tools (E. Jochum, pers. comm.; J.-C. Castel, pers. comm.). The small pieces of chert (silex) found in all peat samples are not convincing indicators of human activity because chert fragments are common in the local Pleistocene and Holocene detritic sediments. Cherty concretions are well known from the Late Jurassic Wettingen Limestone (Kimmerdigian) that forms part of the northern slope of Lägern Hill. When the limestone matrix dissolves by chemical weathering, the cherty nodules are left and can be transported into the valley. This interpretation is confirmed by the presence of other residuals found in sieve residuals of the mammoth peat, i.e. silicified fossils from Late Jurassic echinoderms or phosphatic shark teeth. Furthermore, the chard wood and bone fragments found in the upper mammoth peat and in the thin upper peat (Drescher-Schneider et al., 2007) can be easily explained by sedimentary transport.

It is more likely that the missing part of the skeleton was disrupted by post-sedimentary sliding and slumping, documented by a series of listric faults, cutting through 
the proximal part of the crushed tusks and also thinning out the peat layer from usually 100 to $20-30 \mathrm{~cm}$ (Fig. 7).

Deformation of the mammoth peat and the embedding lake sediments by diapir-like structures and faults was also observed in the 2004 construction pit. In its central part just near the 1890/91 'mammoth pit', most of the peat seems to be affected by resedimentation. Mammoth bones and teeth but also skeletal bones from frogs, vole teeth and a tooth from a hyaena were found in a $1-2 \mathrm{~m}$ thick lens of silt rich in brown organic matter. Most of the bones were found as broken but not worn fragments in the silt together with clasts of typical peat and limestone pebbles, suggesting short transport by floods. Most probably also the disarticulated bone and teeth material from the 1890/91 excavation was recovered from such reworked sediments.

\section{Discussion}

A geological section using the 2-83, 1-83, 85 cores (based on Schlüchter, 1988; Welten, 1988) and the 2003 construction pit at Niederweningen provides a new model of the lithostratigraphic correlation in the Late Pleistocene sequence (Fig. 10). The middle Würmian mammoth peat and its directly overlying lacustrine clay and silt are locally deformed and eroded, especially in the south-eastern to north-eastern areas. Loamy slope deposits and alluvial gravel from a local creek of Late Pleistocene or Holocene age cover a major unconformity, deeply incised at the 1-83 and 2-83 coring sites. A lower peat from the Eemian Interglacial overlies sandy lacustrine deposits with a paleosoil and deeper silty lacustrine deposits of the final part of an older interglacial Welten (1988).
The interdisciplinary studies on the new material from the mammoth site at Niederweningen show that the ca. $1 \mathrm{~m}$ thick compressed peat (with the mammoth skeleton in the uppermost part) developed during a relatively temperate period (interstadial) during the Middle Würmian, hence, the equivalent of Marine Isotope Stage (MIS) 3. The peat formation started after $80,000-70,000 \mathrm{yr}$ ago in a shoaling lake and stopped at about $40,000 \mathrm{yr}$ BP by reflooding. The similar age of a shoaling phase in the core at the neighbouring Oberweningen was mentioned above ( 40,000 yr, Graf and Müller, 1999), suggesting an extended swamp area in the whole valley.

The interstadial section of the mammoth peat at Niederweningen corresponds to the most complete section of the Middle Würmian in lowland Switzerland, that was exposed until a few years ago in a gravel quarry near Gossau, about $15 \mathrm{~km}$ southeast of Zürich (Schlüchter et al., 1987; Preusser et al., 2003). The Gossau-InterstadialComplex lies $35 \mathrm{~km}$ southeast but only $35 \mathrm{~m}$ higher than Niederweningen ( $455 \mathrm{~m}$ a.s.1.) in the same system of the Late Pleistocene Linth glacier. At Gossau, a lower peat (lignite) with a first Picea interstadial (PZ 2-3) was covered by overbank sediments. This first Picea interstadial is dated to $>50,000 \mathrm{yr}$ and followed by a period dominated by Pinus dated to about 50,000 yr ago. On top of the overbank deposits follows a second peat (lignite) that shows a second Picea interstadial (PZ 4) in its lower part. The age of this second Picea interstadial is $42,000 \mathrm{cal}$. yr BP. Comparing the available chronological and palaeoecological information implies a correlation of the mammoth peat at Niederweningen with the upper part of the lower lignite (second Picea interstadial) at Gossau. Vertebrates have not been found at Gossau but some beetles (Coleoptera) are

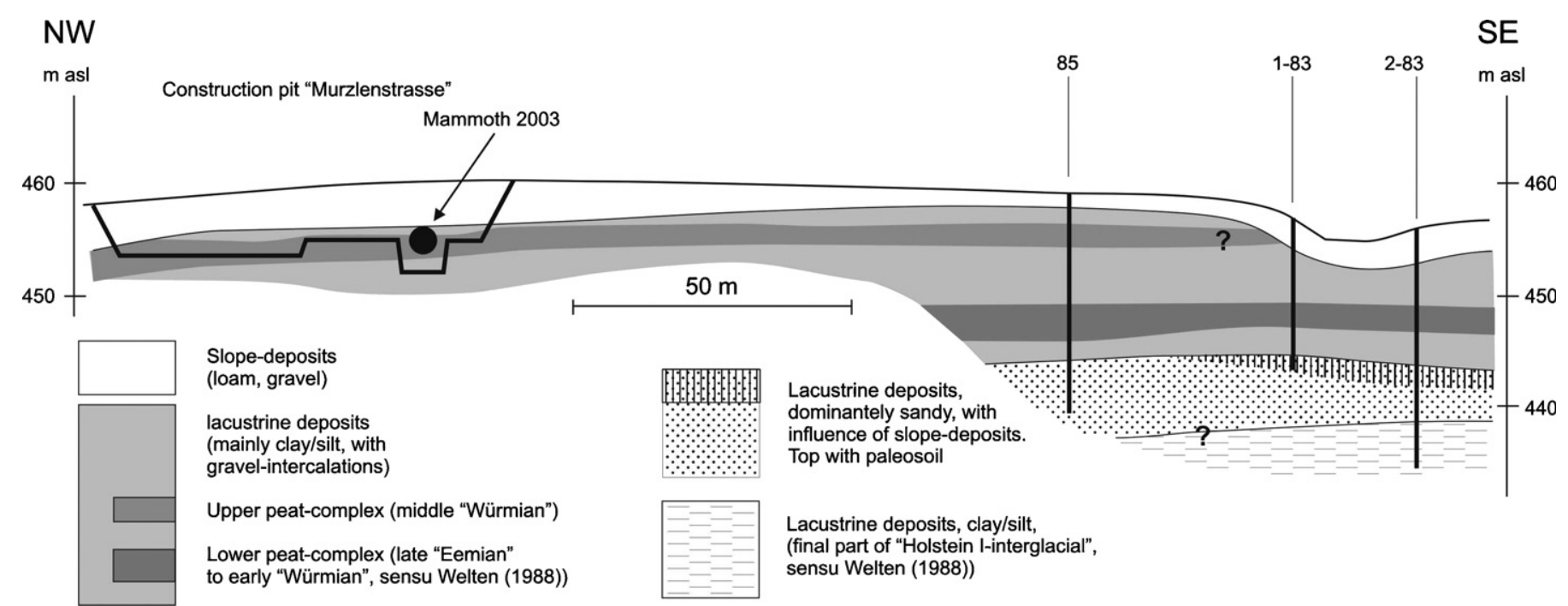

Fig. 10. A geological section through the cores 2-83, 1-83, 85 (based on Schlüchter, 1988; Welten, 1988) and the construction pit 2003 at Niederweningen with the lithostratigraphic correlation in the Late Pleistocene sequence. The middle Würmian upper peat complex (mammoth peat together with overlying lacustrine clay and thin upper peat) is locally deformed and eroded, especially in the south-eastern to north-eastern areas. Loamy slope deposits and alluvial gravel from a local creek of Late Pleistocene or Holocene age cover a major unconformity, deeply incised at the core sites 1-83 and 2-83. A lower peat complex from the Eemian interglacial overlies sandy lacustrine deposits with a paleosoil and deeper silty lacustrine deposits of "Holstein-Iinterglacial" sensu Welten, 1988 (drawing H.R. Graf). 
common at both sides (Jost-Stauffer et al., 2001, 2005; Coope, 2007). The estimated palaeotemperatures are quite similar at Niederweningen and Gossau. While the peat formation at Niederweningen stopped by about $42,000 \mathrm{yr}$ BP due to an environmental change reflected by deposition of fine-grained lacustrine sediments, peat growth at Gossau was interrupted only for short time and continued with a peat dominated by Pinus and Betula vegetation (PZ 5). This peat growth ended with the deposition of gravel.

The uppermost humic horizon at Gossau (PZ 7, ca. 32,000 cal. yr BP) is not recorded at Niederweningen. At this place the interstadial sequence of peat and lacustrine clay and silt was strongly deformed by cryoturbation. The last advance of the Alpine glaciers into lowland Switzerland must have taken place after about 30,000 cal. yr BP and the maximum extent of the LGM occurred at about 21,000 yr ago (Preusser, 2004). Keller and Krayss (2005) date the maximum extent at $24,000 \mathrm{cal}$. yr BP.

Tentative correlations of the Gossau-Interstadial-Complex with other sections in central Europe (Middle Weichselian of northern Germany and The Netherlands) have been discussed by Preusser et al. (2003). The radiocarbon ages of the upper mammoth peat at Niederweningen (Hajdas et al., 2007) suggest correlation to the warm period of the Dansgaard-Oeschger Event 12 in the Greenland ice core record.

The palaeoclimatic interpretation of the Niederweningen mammoth peat and the Gossau-Interstadial-Complex by means of plants and insects indicate climatic conditions between 60,000 and $30,000 \mathrm{yr}$ BP that were quite cooler than today. This contradicts the palaeoecologic interpretation of fossil sites in the central, eastern and southern Alps, where remains of cave bears have been found at an altitude of up to $2800 \mathrm{~m}$ a.s.l. that are attributed to the same period of time according to radiocarbon and $\mathrm{U} / \mathrm{Th}$ dating (Pacher et al., 2004; Rabeder and Hofreiter, 2004; Rabeder et al., 2005). This rises the questions how could strictly vegetarian cave bears survive in altitudes of about $2000 \mathrm{~m}$ a.s.l. (e.g. Contourines, I, $2800 \mathrm{~m}$ a.s.1., Drachenloch, $\mathrm{CH}, 2475 \mathrm{~m}$ a.s.1., Salzofen, A, $2055 \mathrm{~m}$ a.s.l., Brieglersberg, A, $2014 \mathrm{~m}$ a.s.l., Ramesch, A, $1960 \mathrm{~m}$ a.s.1.) when the timberline was only at $600-800 \mathrm{~m}$ a.s.1.

\section{Acknowledgements}

The excavation of the fossil material from the 2003 and 2004 construction pits was very successful thanks to the work of many collaborators of the Palaeontological Institute and Museum of Zurich University, the Archaeological Survey of Kanton Zürich and several volunteers. Logistic and financial support were made by the architects Lüthi + Partner (Regensberg), the municipality of Niederweningen, the Verein für Ortsgeschichte Niederweningen and the Swiss Commission on Quaternary Research. The University of Zürich subsidised the conservation of the fossils, carried out by U. Oberli (St. Gallen), and the Archaeological Survey of Kanton Zürich financed initial studies on geology (H.R. Graf), radiocarbon dating (G. Bonani and I. Hajdas), pollen analyses (R. DrescherSchneider), wood determination (W. Schoch), other palaeobotanical studies (C. Jacquat) and identification of beetles (R. Coope). We also thank other specialists such as W. Brinkmann (Palaeontology, University of Zürich) who made the morphological description of the vertebrate fossils, E. Jochum (Archaeological Survey of Kanton Zürich) and J.-C. Castel (Muséum d'histoire naturelle de Genève) who looked for signs of human activity. R. Kindlimann (Aathal) made some illustrations; D. Hoesli, D. Pelagatti and A. Dettwyler (Atelier Bunter Hund, Zürich) painted the environmental reconstructions for the Mammutmuseum Niederweningen. C. Hill, G. Rabeder and F. Preusser greatly improved the paper by their comments and remarks.

Further information regarding the mammoth museum established in 2005 at Niederweningen can be found at www.mammutmuseum.ch

\section{References}

Aubry, D., Braillard, L., Guelat, M., Stalder, L., Stahl Gretsch, L., 2005. Mensch und Umwelt. Archäologie der Schweiz 28, 6-16.

Blumenbach, J.F., 1799. Handbuch der Naturgeschichte. 6. Aufl. Dieterich, Göttingen, 708pp.

Bocherens, H., 2003. Isotopic biogeochemistry and the paleoecology of the mammoth steppe fauna. In: Reumer, J.W.F., De Vos, J., Mol, D. (Eds.), Advances in Mammoth Research (Proceedings of the Second International Mammoth Conference, Rotterdam, May 16-20 1999), Deinsea, vol. 9, pp. 57-76.

Burger, J., Rosendahl, W., Loreille, O., Hemmer, H., Erikson, T., Götherström, A., Hiller, J., Collins, M.J., Wess, T., Alt, K.A., 2004. Molecular phylogeny of extinct cave lion Panthera leo spelaea. Molecular Phylogenetics and Evolution 30, 841-849.

Coope, R., 2007. Coleoptera from the 2003 excavations of the mammoth skeleton at Niederweningen, Switzerland. Quaternary International, this volume.

Drescher-Schneider, R., Jacquat, C., Schoch, W., 2007. Palaeobotanical investigations of the mammoth site of Niederweningen, Switzerland. Quaternary International, this volume.

Engesser, B., Fejfar, O., Major, P., 1996. Das Mammut und seine ausgestorbenen Verwandten. Veröffentlichungen naturhistorisches Museum Basel 20, 188pp.

Furrer, H., 2005. Niederweningen, die bedeutendste Mammutfundstelle der Schweiz-Neufunde und eigenes Mammutmuseum. Bulletin angewandte Geologie 10/2, 61-69.

Graf, H., Müller, B., 1999. 7. Das Quartär: Die Epoche der Eiszeiten. In: Bolliger, T. (Hrsg.), Geologie des Kantons Zürich, Ott Verlag, pp. 71-95.

Guthrie, R.D., 1982. Mammals of the Mammoth Steppe as palaeoenvironmental indicators. In: Hopkins, D.M., Matthews, Jr., J.V., Schweger, C.E., Young, S.B. (Eds.), Paleoecology of Beringia. Academic Press, New York, pp. 307-329.

Guthrie, R.D., 2004. Radiocarbon evidence of mid-Holocene mammoths stranded on an Alaskan Bering Sea island. Nature 429, 746-749.

Hajdas, I., Bonani, G., Furrer, H., Mäder, A., Schoch, W., 2007. Radiocarbon Chronology of the Mammoth Site at Niederweningen, Switzerland-results from dating bones, teeth, wood and peat. Quaternary International, this volume.

Heim, A., 1919. Geologie der Schweiz, Band 1. Tauchnitz, Leipzig.

Hünermann, K.A., 1985. Eiszeit-Säugetiere aus dem Kanton Zürich. Vierteljahresschrift der naturforschenden Gesellschaft Zürich 130/3, 229-250. 
Hünermann, K.A., 1987. Faunenentwicklung im Quartär. Mitteilungen der naturforschenden Gesellschaft Luzern 29, 151-171.

Hünermann, K.A., 1989. Die Wühlmäuse (Mammalia, Rodentia, Arvicolidae) in der Jungpleistozänen Wirbeltierfauna von Niederweningen, Kanton Zürich. In: Rose, J., Schlüchter, Ch. (Eds.), Quaternary Type Sections: Imagination or Reality (Proceedings of the Inqua-Subcommission on European Quaternary Stratigraphy, Zürich 14-15 October 1985). Balkema, Rotterdam, pp. 151-159.

Jost-Stauffer, M., Coope, G.R., Schlüchter, Ch., 2001. A coleopteran fauna from the middle Würm (Weichselian) of Switzerland and its bearing on palaeobiogeography, palaeoclimate and palaeoecology. Journal of Quaternary Science 16, 257-268.

Jost-Stauffer, M., Coope, G.R., Schlüchter, Ch., 2005. Environmental and climatic reconstructions during Marine Oxygen Isotope Stage 3 from Gossau, Swiss Midlands, based on coleopteran assemblages. Boreas $34,53-56$.

Keller, O., Krayss, E., 2005. Der Rhein-Linth-Gletscher im letzten Hochglazial. 2. Teil: Datierung und Modelle der Rhein-LinthVergletscherung. Klima-Rekonstruktionen. Vierteljahresschrift der naturforschenden Gesellschaft Zürich 150 (3-4), 69-85.

Kuzmin, Y.V., Orlova, L.A., Zolnikov, I.D., 2003. Dynamics of the mammoth (Mammuthus primigenius) population in Northern Asia: radiocarbon evidence. Annals of the Natural History Museum Rotterdam 9, 221-237.

Lang, A., 1892. Geschichte der Mammutfunde. Ein Stück Geschichte der Paläontologie, nebst einem Bericht über den schweizerischen Mammutfund in Niederweningen 1890/91. Neujahrsblatt der naturforschenden Gesellschaft Zürich 44, 2-35.

Le Tensorer, J.-M., Niffeler, U. (Eds.), 1993. Die Schweiz vom Paläolithikum bis zum frühen Mittelalter (SPM). Vom Neandertaler zu Karl dem Grossen. Bd. 1: Paläolithikum und Mesolithikum, Basel, 114pp.

Lister, A.M., Sher, A., 2001. The origin and evolution of the woolly mammoth. Science 294, 1094-1097.

MacPhee, R.D.E., Tikhonov, A.N., Mol, D., de Marliave, C., van der Pflicht, H., Greenwood, A.D., Flemming, C., Agenbroad, L., 2002. Radiocarbon chronologies and extinction dynamics of the Late Quaternary mammalian megafauna of the Taimyr Peninsula, Russian Federation. Journal of Archaeological Science 29, 1017-1042.

Mead, J.I., Agenbroad, L.D., Davis, O.K., Martin, P.S., 1986. Dung of Mammuthus in the arid southwest, North America. Quaternary Research 25, 121-127.

Olivier, R.C.D., 1982. Ecology and behaviour of living elephants: bases for assumptions concerning the extinct woolly mammoths. In: Hopkins, D.M., Matthews, Jr., J.V., Schweger, C.E., Young, S.B. (Eds.), Paleoecology of Beringia. Academic Press, New York, pp. 291-305.

Pacher, M., Pohar, V., Rabeder, G. (Eds.), 2004. Potocka zijalka. Palaeontological and archeological results of the campaigns 1997-2000. Mitteilungen der Kommission für Quartärforschung der Österreichischen Akademie der Wissenschaften, vol. 13, pp. 1-245.

Preusser, F., 2004. Towards a chronology of the Late Pleistocene in the northern Alpine Foreland. Boreas 33, 195-210.
Preusser, F., Degering, D., 2007. Luminescence dating of the Niederweningen mammoth site, Switzerland. Quaternary International, this volume.

Preusser, F., Geyh, M.A., Schlüchter, Ch., 2003. Timing of Late Pleistocene climate change in lowland Switzerland. Quaternary Science Reviews 22, 1435-1445.

Rabeder, G., Hofreiter, M., 2004. Der neue Stammbaum der Höhlenbären. Die Höhle 55, 58-77.

Rabeder, G., Hofreiter, M., Wild, E., 2005. Die Bären der Brieglersberghöhle (1625/24). Die Höhle 56, 36-43.

Schlüchter, Ch., 1988. Neue geologische Beobachtungen bei der Mammutfundstelle Niederweningen (Kt. Zürich). Vierteljahresschrift der naturforschenden Gesellschaft Zürich 133, 99-108.

Schlüchter, Ch., 1994. Das Wehntal-Eine Schlüsselregion der Eiszeitenforschung. Jahrheft des Zürcher Unterländer Museumsvereins 28, 4-24.

Schlüchter, Ch., Maisch, M., Suter, J., Fitze, P., Keller, W.A., Burga, C.A., Winistorf, E., 1987. Das Schieferkohlen-Profil von Gossau (Kanton Zürich) und seine stratigraphische Stellung innerhalb der letzten Eiszeit. Vierteljahresschrift der naturforschenden Gesellschaft Zürich 132, 135-174.

Strunk, H., 1983. Pleistocene diapiric upturnings of lignites and clayey sediments as periglacial pheneomena in Central Europe. In: Proceedings of the fourth International Conference on Permafrost, 1200-1204. National Academy Press, Washington, DC.

Tütken, T., Furrer, H., Vennemann, T.W., 2007. Stable isotope compositions of mammoth teeth from Niederweningen, Switzerland: Implications for the Late Pleistocene climate, environment and diet. Quaternary International, this volume.

Vartanyan, S.L., Garutt, W.E., Sher, A.V., 1993. Holcene dwarf mammoths from Wrangel Island in Siberian Arctic. Nature 362, 337-340.

Vereshchagin, N.K., Baryshnikov, G.F., 1982. Paleoecology of the mammoth fauna in Eurasian artic. In: Hopkins, D.M., Matthews, Jr., J.V., Schweger, C.E., Young, S.B. (Eds.), Paleoecology of Beringia. Academic Press, New York, pp. 267-279.

Wegmüller, S., 1992. Vegetationsgeschichtliche und stratigraphische Untersuchungen an Schieferkohlen des nördlichen Alpenvorlandes. Denkschriften der schweizerischen Akademie der Naturwissenschaften 192, 1-82.

Weidmann, M., 1970. Le mammouth de Praz-Rodet (Le Brassus, Vaud). Note préliminaire. Bulletin des Laboratoires de Géologie, Minéralogie, Géophysique et du Musée Géologique de l'Université de Lausanne $179,1-12$.

Welten, M., 1988. Neue pollenanalytische Ergebnisse über das Jüngere Quartär des nördlichen Alpenvorlandes der Schweiz (Mittel- und Jungpleistozän). Beiträge zur geologischen Karte der Schweiz N.F. 162, 40pp.

Ziegler, R., 1994. Das Mammut (Mammuthus primigenius BlumenBaCH) von Siegsdorf bei Traunstein (Bayern) und seine Begleitfauna. Münchner Geowissenschaftliche Abhandlungen (A) 26, 49-80. 